\title{
Antonio Bioni and His Compositions Preserved in Kroměříž Archive
}

\author{
Zuzana Černá / 111040@mail.muni.cz
}

Department of Musicology, Faculty of Arts, Masaryk University, Brno, CZ

\begin{abstract}
This study deals with Italian composer Antonio Bioni (c. 1698-?) and his compositions deposited in the Kromeřriž music collection. Along with a summary of current research, it also offers new findings about his life and work. Bioni belongs to important propagators of Italian musical culture to regions beyond the Alps in the first half of the 18th century. In his life and work we can see how music centres in the first half of the 18th century - Prague, Wrocław, Jaroměřice nad Rokytnou and Vienna - were interconnected. One part of the study presents analysis of Bioni's cantata Innocente è il mio martire, stored in Kroměříž, which probes Bioni's compositional style.
\end{abstract}

\section{Keywords}

Antonio Bioni, Italian opera, 18th century, Prague, Kuks, Wrocław, Jaroměřice nad Rokytnou, Vienna, Count Johann Adam Questenberg, Count Franz Anton Sporck, Kroměříž music collection, musical analysis, musical-rhetorical figures, galant style 
This study, dealing with Italian composer Antonio Bioni (app. 1698-?) and his compositions from the Kroměříž music collection, offers (apart from a summary of existing research about Bioni's life and work) little known information about compositions from this archives and also analysis of one of these compositions. ${ }^{1}$

Antonio Bioni belongs to important propagators of Italian musical culture to the regions beyond the Alps in the first half of the 18th century. His journey ran from Italy to the Czech lands, where his stays in Prague, Kuks and especially in Wrocław ${ }^{2}$ are documented. Bioni's name also appears in connection with musical activities in Jaroměřice nad Rokytnou and with Count Johann Adam von Questenberg. So far the last records about Bioni's life are from Vienna. ${ }^{3}$

Bioni belongs to those authors about whose lives we do not have much information and most of whose works are lost. Among period literature, Mathesson's important tract Grundlage einer Ehrenpforte of 1740 contains information from the time of Bioni's activities in Wrocław. ${ }^{4}$ In Czech musicological literature Bioni's name first appears in the writings of Vladimír Helfert. ${ }^{5}$ His work was followed by that of Jana Perutková, who in her new publications about musical life in Jaroměřice in the first half of the 18th century focuses also on Bioni and his operatic works, which are associated with musical activities at the court of Count Questenberg. ${ }^{6}$ Daniel Freeman, Stanislav Bohadlo and Milada Jonášová also turn their attention to Bioni and present new information about his stays in Prague and Kuks (the seat of Count Franz Anton Sporck). ${ }^{7}$ Italian opera in Silesian Wrocław is at present being analysed by Jana Spáčilová, who in her latest study deals among other things with Bioni's opera Endimione. ${ }^{8}$ Foreign musicologists who

1 The present text is an extended version of „Antonio Bioni a jeho skladby dochované v kroměřžském archivu“, which was delivered at the international musicological conference Musica Antiqua et Musica Nova held at the Janáček Academy of Performing Arts in Brno, 5-7 December 2016. The author also links the text to her diploma thesis - VEVERKOVÁ, Zuzana. Antonio Bioni a jeho kantáta Innocente v kroměřžšé hudebni sbírce. Bachelor thesis (supervisor: Jana Spáčilová), Department of Musicology, Faculty of Arts, MU Brno 2009. Bioni and especially his opera Issipile is the topic of the author's dissertation thesis (the supervisor is Jana Perutková, Department of Musicology, Faculty of Arts, MU Brno).

2 Wrocław in Bioni's times was a part of Lands of the Bohemian Crown.

3 For more details see VEVERKOVÁ, Zuzana. Antonio Bioni - životní osudy a tvorba neznámého skladatele. Opus musicum, 2012, vol. 44, Nr. 3, pp. 38-47; and ČERNÁ, Zuzana. Antonio Bioni: „operista“ mezi Prahou, Kuksem, Vratislaví, Jaroměřicemi a Vídní. Clavibus unitis, Praha: Nadace pro dějiny kultury ve střední Evropě, vol. 2014, Nr. 3, pp. 151-160.

4 MATTHESON, Johann. Grundlage einer Ehrenpforte (Hamburg 1740), hrsg. von Max Schneider. Graz: Akademische Druckund Verlagsanstalt, 1994, pp. 374-378.

5 HELFERT, Vladimír. Hudebni barok na českých zámcích. Jaroměřice za hraběte Jana Adama z Questenberku († 1752). Praha: Česká akademie císaře Františka Josefa pro vědy, slovesnost a umění, 1916.

6 PERUTKOVÁ, Jana. František Antonín Míca ve službách hraběte Questenberga a italská opera v Jaroměricích. Praha: KLP - Koniasch Latin Press, 2011; PERUTKOVÁ, Jana. Der glorreiche Nahmen Adami. Johann Adam Graf von Questenberg (1678-1752) als Förderer der italienischen Oper in Mähren. Wien: Hollitzer Verlag, 2015.

7 FREEMAN, E. Daniel. The Opera Theater of Count Franz Anton von Sporck in Prague. Studies in Czech Music 2. Stuyvesant - New York: Pendragon Press, 1992. BOHADLO, Stanislav. Questenberg a Sporck - oddělené a nezávislé barokní hudební subkultury na Moravě a v Čechách? Musicologica Brunensia, 2011, vol. 46, Nr. 1-2, pp. 15-34. JONÁŠOVÁ, Milada. I Denzio: tre generazioni di musicisti a Venezia e a Praga. Hudebni věda, 2008, vol. XLV, Nr. 1-2, pp. 57-114.

8 SPÁČILOVÁ, Jana. Počátky opery ve Slezsku - současný stav pramenů. Musicologica Brunensia, 2016, vol. 
have recently published important works include Michał Bristiger and Reinhard Strohm (a newly discovered opera Andromaca from 1730), ${ }^{9}$ Hanna Schodterer (the serenata $L a$ pace fra la virtù e la bellezza from 1739) ${ }^{10}$ and Rashid-Sascha Pegah, who discovered hitherto unknown Bioni cantatas in the State Library of German Ansbach. ${ }^{11}$

\section{Bioni's life and career}

Antonio Bioni was born in Venice probably in $1698 .{ }^{12}$ Here he studied composition with Giovanni Porta. ${ }^{13}$ Altogether he had apparently written three operas in Italy before he left for the area beyond the Alps: Climene (1721, Chioggia), Mitridate (1722, Ferrara) and Cajo Mario (1722, Ferrara). It is wrongly assumed that his following opera is Udine which was premiered in Venice. ${ }^{14}$ In fact it was the opera Climene which had its subsequent premiere in 1722 in Udine; in the preserved text Bioni is named with the attribute "di Venezia" which might have caused the mistake. ${ }^{15}$ Before starting his career as a composer, he performed in operas as a singer. ${ }^{16}$

An important turning point in Bioni's life is the year 1724, when he came to Bohemia. He was given a contract as an opera composer by impresario, librettist and singer

51, Nr. 2, pp. 157-170. Another study which deals with Italian opera in Czech lands and mentions Bioni is SPÁČILOVÁ, Jana. Sarriho opera Didone v Brně (1734) a její rekonstrukce pro novodobé provedení (2014). Opus musicum, 2014, vol. 46, Nr. 1, pp. 18-31.

9 BRISTIGER, Michal - STROHM, Reinhard. „Libertà, marito e trono fur miei beni...“: Die wiederentdeckte Andromaca von Antonio Bioni (Breslau 1730). In Opera Subjects and European Relationships [= Italian Opera in Central Europe, 1618-1780, Bd. 3]. Dubowy, Norbert - Herr, Corinna - Żórawska - Witkowska, Alina (eds.), Berlin: BWV, 2007, pp. 73-109.

10 SCHODTERER, Hanna. Pietro Antonio Metastasios Azione teatrale, La pace fra la virtù e la bellezza in Vertonungen für den Wiener Hof von Luca Antonio Predieri und Antonio Bioni. Master thesis (supervisor: Reinhard Strohm), Universität Wien, Wien 2011.

11 PEGAH, Rashid-Sascha. Antonio Bioni und seine „Cantate Musicali“ für Markgräfin Friderique Louise von Brandenburg-Ansbach. Jahrbuch für fränkische Landesforschung, 2012, roč. 72, pp. 185-198. It is an undatet collection of six cantatas Cantate Musicali devoted to margravine Friderique Louise von Brandenburg-Ansbach.

12 This year is mentioned for the first time in FÉTIS, François Joseph. Bioni Antoine. Biographie universelle des musiciens et bibliographie générale de la musique. Tome premier. Paris: Librairie de Firmin-Didot, 1883, p. 421.

13 WALTHER, Johann Gottfried. Bioni Antonio. Musikalisches Lexikon oder musikalische Bibliothek 1732 / J. G. Walther; herausgegeben von Richard Schaal. Kassel: Bärenreiter, 1953, pp. 94-95.

14 HANSELL, Sven - FREEMAN, E. Daniel. Bioni, Antonio. The New Grove dictionary of music and musicians. Volume 3, Baxter to Borosini / edited by Stanley Sadie; executive editor John Tyrrell. 2nd ed. New York: Grove, 2001, p. 602. Compare also FÉTIS, op. cit.

15 My thanks for bringing my attention to the libretto belong to Ms. Jana Perutková. The libretto is deposited in the Central National Library of Rome (I-Rn, 35. 6.B.2.5.) and is available here: https://books. google.cz/books?id=zLJpDclIX6wC\&pg=PA11\&lpg=PA11\&dq=Antonio+Bioni+Udine\&source=bl\&ots=NaiepG4eA9\&sig=6vslo7JKvIj1uKbk-dWDCnSCp3o\&hl=cs\&sa=X\&ved=0ahUKEwiVnr-_pP7VAhWFOsAKHXVMDpgQ6AEIZzAJ\#v=onepage\&q=Antonio\%20Bioni\%20Udine\&f=false.

16 For more details see ČERNÁ, op. cit., p. 152; Librettos of the operas in which Bioni performed are listed by SARTORI, Claudio. I libretti italiani a stampa dalle origini al 1800: catalogo analitico con 16 indici. Cuneo: Bertola \& Locatelli, 1990-1994. Compare also BRISTIGER - STROHM, op. cit., p. 74. 
Antonio Denzio, who was supposed to put together an opera company in Venice for impresario Antonio Maria Peruzzi in Prague. In March 1724 Peruzzi was granted permission from the local vice-regency to perform Italian opera in Manhardt's house in the Old Town of Prague. ${ }^{17}$ Thus, in 1724, Denzio and Peruzzi made a contract to form an opera company for Prague. ${ }^{18}$ However, following Peruzzi's agreement with Count Franz Anton Sporck in June 1724, Denzio brought the opera company first to Kuks and only in autumn 1724 to Prague..$^{19}$ In both places the opera Orlando furioso, composed to Grazio Braccioli's libretto, was performed. The main role was sung by Antonio Denzio. However, the authorship of the opera is unclear. Besides Antonio Bioni the composer might also have been Antonio Vivaldi, who wrote this opera in 1714 and kept in touch with Denzio. ${ }^{20}$ The authorship of this opera has been lately analysed by Michał Bristiger and Reinhard Strohm, who attribute the authorship to Bioni who, however, used part of the arias from Vivaldi's and Ristori's version..$^{21}$ Czech musicologist Stanislav Bohadlo, on the other hand, believes that Bioni is the only author. He bases his belief on a remark by household poet Gottfried Benjamin Hancke, who translated the Italian libretto of the opera Orlando furioso into German for its performance in Kuks. In his letter to Sporck's Hofmeister, Tobias Antonin Seeman, Hancke criticizes music for the opera and attributes the authorship to Bioni. ${ }^{22}$ According to Jana Spáčilová, the authorship of at least part of the music is unquestionable and from her point of view the proof is the Brno libretto to Orlando furioso, which is - similarly to other librettos from that time - identical with the Prague libretto, and because the authorship of this one is assigned Vivaldi - "apart from several arias" which were written by Bioni. ${ }^{23}$ The opera Orlando furioso was perhaps a pasticcio on which both composers collaborated..$^{24}$ Even despite a not entirely clearly proved authorship it is obvious that this opera was very successful, and after its performance at Kuks and in Prague was also played in Wrocław $(1725,1734)$, in Carlsbad

17 BOHADLO, Stanislav. Antonio Denzio. Starši divadlo v českých zemích do konce 18. století. Osobnosti a dila, ed. A. Jakubcová. Praha: Divadelní ústav - Academia, 2007, pp. 133-137, here p. 134.

18 For more about this contract see BOHADLO, op. cit., s. 134. Original version of the contract see FREEMAN, 1992, op. cit., pp. 281-284.

19 BOHADLO, 2011, op. cit., p. 18.

20 Vivaldi's opera Orlando furioso from 1714 is an adaptation of a one-year older work by Giovanni Alberto Ristori. For more see SPÁČILOVÁ, Jana. Antonio Vivaldi a italská opera v Brně: Orlando furioso a Tullo Ostilio (1735). Opus musicum, 2008, vol. 40, Nr. 4, pp. 22-27, here pp. 25-26.

21 BRISTIGER - STROHM, op. cit., p. 76.

22 BOHADLO, 2011, op. cit., pp. 19-20. Compare also FREEMAN, Daniel E. Orlando furioso in the Bohemian Lands: Was Vivaldi's Music really used? Informazioni e studi vivaldiani, 14, 1993, pp. 51-73.

23 SPÁČILOVÁ, 2008, op. cit., pp. 25-26.

24 In regard to the opera Orlando furioso's authorship it is necessary to point out that recently a manuscript has been discovered and Michael Talbot assigned it as an overture from opera Orlando furioso and as an author he indicated Bioni. The overture will be a subject of further research. The overture is stated by RISM: Bioni, Antonio. Orlando furioso (Excerpts). [online].[cit. 2017-09-10]. Available at: https://opac.rism.info/ search?id=800273643, https:/ / opac.rism.info/search?id=703000484. 
(summer 1726 $)^{25}$, in Brussels $(1727)^{26}$, in Brno $(1735)^{27}$ and in Graz $(1737)^{28}$. Bioni's presence at these performances has not been documented so far..$^{29}$

An Italian opera company under impresario Peruzzi's leadership operated in Prague till 1725. Sporck's theatre opened on 23 October 1724 with the above mentioned opera Orlando furioso, which due to its great success was repeated during the Advent. ${ }^{30}$ At the end of 1724 the Carnival season opened with the opera L'innocenza giustificata with music by Bioni and other composers. ${ }^{31}$ However, due to conflicts between Peruzzi and Denzio, in 1725 Peruzzi together with other unsatisfied members of his troupe left for Wroclaw and here he founded a new opera company. According to Bohadlo, Count Sporck himself suggested establishing the Italian opera in Wrocław, largely because of Silesian aristocrats' and merchants' frequent visits to opera performances at Kuks. ${ }^{32}$ The company settled down in the Ballhouse on Breitestrasse and operated there till its end in $1734 .^{33}$ Bioni came to Wroclaw no later than 1726 and worked there as a music teacher, cembalist, Kapellmeister and composer. ${ }^{34}$ Before his arrival in Wrocław, his stay in Venice has been documented: there he met Antonio Vivaldi. ${ }^{35} \mathrm{He}$ also probably resided in Prague in November 1725 when his opera Armida abbandonata was performed.

In 1731 Bioni was named court composer to the Prince-Bishop of Breslau (Wroclaw) and Archbishop-Elector of Mainz Franz Ludwig von Neuburg. ${ }^{36}$ In the same year he also became an impresario in the Wrocław opera company and he led it till 1734, when it

25 The evidence of the performance is Count Sporck's letter to Karel Joseph de Grossa dated 18 July 1726 ; see FREEMAN, 1992, op. cit. p. 110.

26 Ibid, p. 111. In 1727 Peruzzi is documented as an impresario (BOHADLO, Stanislav - JONÁŠOVÁ, Milada. Peruzzi, Antonio Maria. Stař̌i divadlo v českých zemích do konce 18. století. Osobnosti a dila, ed. A. Jakubcová. Praha: Divadelní ústav - Academia, 2007, pp. 451-452.

27 SPÁČILOVÁ, 2008, op. cit., pp. 25-26.

28 BOHADLO, 2011, op. cit., p. 18.

29 In literature there is also a note about the opera Orlando furioso being performed in Baden-Baden. The authors probably base this idea on Fétis (FÉTIS, op. cit., p. 421) who states that Bioni composed Orlando furioso already in 1723 and in 1724, before its performance in Prague, it had been played in Baden-Baden. However, in the original version Fétis mentions "Bade" which can mean that he was referring to Kuks, a spa city.

30 BOHADLO, 2007, op. cit., p. 135.

31 It was a pasticcio in which Bioni composed 11 out of 28 music pieces and also some recitatives; the other music was composed by Fioré, Vivaldi, Capelli, Porta and Gasparini (BRISTIGER - STROHM, op. cit., p. 76).

32 BOHADLO, 2011, op. cit., p. 20.

33 More about Italian opera in Wrocław: MATTHESON, SPÁČILOVÁ 2016 and WĘGRZYN - KLISOWSKA, Walentyna. Barokowy teatr operowy we Wroctawiu 1725-1734. Wrocław: Polskie Stowarzyszenie Pedagogów Śpiewu, 2006.

34 According to Borcherdt Bioni made his début in Wrocław with opera Armida abandonata in May 1726 (BORCHERDT, Hans Heinrich. Geschichte der italienischen Oper in Breslau. Zeitschrift des Vereins für Geschichte Schlesiens. 1910, vol. 44. pp. 18-51, here p. 27). Mathesson introduces Bioni only in connection with his own opera Armida al Campo's performance in June 1726 : „[...],, Signore Bioni kam nunmehro selbst nach Breslau, und verfertigte die Composition sehr glücklich dazu, spielte auch selber den ersten Clavicimbel. (MATTHESON, op. cit., p. 375).

35 BRISTIGER - STROHM, op. cit., pp. 74-75.

36 BORCHERDT, op. cit., p. 37. 
closed for financial reasons. ${ }^{37}$ In Wrocław Bioni composed 24 out of his 42 operas; these were performed in Wrocław between 1725 and $1734 .{ }^{8}$

During his activities in Wrocław Bioni kept up contacts not only with Prague but also with Vienna. In 1727 at the Kärtnertortheater, Bioni's opera Endimione, written for Wrocław, was performed. ${ }^{39}$ In 1729 Bioni might have been present in Vienna as well, namely for the premiere of his opera I cacciatori feriti d'amore, which was also performed in the Kärntnertortheater. ${ }^{40}$ Bioni's stays in Prague are then documented in $1727^{41}$, $1730^{42}$ and in summer or autumn of 1734 , when Bioni unsuccessfully tried to obtain permission to perform operas.$^{43}$ Likely, however not documented, is his presence for the introduction of his operas in Sporck's theatre in Prague - Il ritorno del figlio con l'abito più approvato (pasticcio, carnival 1730) ${ }^{44}$ and Adone (pastorale per musica, carnival 1731).

After the break-up of the opera company, in the period of 1734-1738, there are no clear records about Bioni. It is only known that by 1738 he kept a flat in Wroclaw, ${ }^{45}$ presumably in case he succeeded in re-establishing the opera company. It is possible that he also traveled to Jaromerrice nad Rokytnou, the seat of the Italian opera lover Count Johann Adam Questenberg. In 1737 the opera Issipile was performed here and its music was most likely composed by Bioni. ${ }^{46}$ If this was true, then it is possible that Bioni was at the premiere in Jaroměřice in person. However, there is no definite evidence. There are just some notes in the correspondence of Count Questenberg with Jaroměřice administrators about studying Issipile, from which we find out that in autumn 1737 this opera was being prepared together with Merope by Riccardo Broschi, and that their performances are believed to have been attended by an Abbe from Venice who would probably have been able to grasp the sense of music. ${ }^{47}$ The opera Issipile was written by Bioni for Wrocław, where it was first introduced in autumn 1732. It is a dramma per musica to Pietro Metastasio's libretto. Furthermore, Issipile is Bioni's only completely preserved opera. The unique score

37 For the reasons for the end of opera in Wrocław see BORCHERDT, op., cit., p. 40.

38 For the list of performed operas in Wrocłav in 1725 - 1734 see SPÁČILOVÁ, 2016, op., cit., pp. 165-167. Also compare MATTHESON, op. cit., pp. 374-378.

39 BRISTIGER - STROHM, op. cit., p. 82.

40 PERUTKOVÁ, 2015, op. cit., p. 208. Both Italian and German librettos have been preserved. The German libretto is in Heinrich Rademin's translation (Die von der Liebe verwundete Jäger). Both librettos are deposited in the Harvard University library in the USA (US-CAh): GC7 A100 B750 vol. 114 No. 870, GC7 A100 B750 vol. 123. Thank to Jana Spáčilová for bringing the Italian libretto to my attention.

41 This stay has been documented thanks to calendar entries of Sporck's household steward Tobias Anton Seeman (BOHADLO, 2011, op. cit., p. 21-23.). It arises from these entries that Bioni left Prague for Kuks and then for Wrocław (Ibid., p. 22).

42 Milada Jonášová has found out that Bioni was a godfather at the baptism of Giovanni Antonio Guerra's son. Guerra was a singer and an occasional composer in Denzio's company. This baptism was held on 2 December 1730 in Prague (JONÁŠOVÁ, op. cit., p. 89).

43 FREEMAN, 1992, op. cit., p. 67.

44 Other authors are Mancini and Lucchini.

45 BORCHERDT, op. cit., p. 41.

46 PERUTKOVÁ, 2011, op. cit., p. 51.

47 PERUTKOVÁ, 2015, op. cit., p. 484. 
originally from the possession of Count Questenberg is deposited in Vienna. ${ }^{48}$ A libretto was preserved only from the Wrocław performance in 1732 and is deposited in Milan. ${ }^{49}$ Thanks to Helfert we also know that apart from Issipile Count Questenberg owned copies of Bioni's operas Engelberta and Griselda, which according to Mattheson was a pasticcio. ${ }^{50}$

Between 1738 and 1739 Bioni resided in Vienna. ${ }^{51}$ In 1738, his opera Girita was performed at the Kärntnertortheater. Dates of its performances are known due to letters of Georg Adam Hoffmann, Count Questenberg's household steward. ${ }^{52}$ Bioni perhaps might have aspired to a position at the imperial court. This is indicated by the fact that in the Department of Music of the Austrian National Library in Vienna there is a score of Bioni's serenata La pace fra la virtù e la bellezza from $1739 .{ }^{53}$ It is a serenata à 5 voci con stromenti, in which Bioni is reported to be both the composer and also a singer. ${ }^{54}$ In other parts there were amateur women singers from important aristocrat families, as is apparent from the score's dedication. ${ }^{55}$ It is interesting that in October 1738 in Vienna a serenata with the same title by Italian composer Luca Antonio Predieri was performed; Predieri came from Italy to Vienna in 1737 and in 1739 he attained a position of ViceKapellmeister at the imperial court. Both compositions were written to the eponymous libretto by Pietro Metastasio, and both were dedicated to archduchess Maria Theresia. ${ }^{56}$ Thus at the same time two composers set the same libretto to music for the same occasion. Maybe it was a sort of competition for the position of Vice-Kapellmeister, which was finally given not to Bioni but to Predieri. Vienna is also the last place of Bioni's activities about which we have some information. Thanks to Rashid-Sasha Pegah we know that in 1741 Bioni was still in Vienna. In his study, which deals with a newly discovered collection of six Bioni cantatas, Pegah cites entries from the diary of Duke Anton Ulrich von Sachsen-Meiningen-Coburg. ${ }^{57}$ The Duke refers to Bioni as a successful organizer of concerts in Vienna; the last reference about him comes from 16 March $1741 .{ }^{58}$ These memoirs provide the last known evidence of Bioni's life so far. ${ }^{59}$

48 A-Wgm, IV 27740 (Q1214); see also PERUTKOVÁ, 2011, op. cit., p. 51 and p. 93.

49 I-Mb, Racc.dram.5675/002; SARTORI, op. cit., III, [E-K], p. 50.

50 HELFERT, op. cit., pp. 204-205. „Zusammengestellt aus Werken von Boniventi, Caldara, Capelli, Gasparini, Giacomelli, Händel, Orlandini, Porpora, Porta, Sarro, Giovanni Verocai (Violinist der Breslauer Oper), Vinci und Vival$d i^{“}$ (MATTHESON, op. cit., p. 376).

51 For more details see ČERNÁ, op. cit., p. 156-157.

52 PERUTKOVÁ, 2011, op. cit., p. 51.

53 A-Wn, Mus. Hs. 16516.

54 For more details see ČERNÁ, op. cit., p. 152. Compare also SCHODTERER, op. cit.

55 „...nuova mia composizione musicale, che sarà cantata da persone nobili di detta città... " For more information about the performance see SCHODTERER, op. cit, pp. 96-101.

56 Settings of Metastasio's text to music by Predieri and Bioni are discussed in a master's thesis by Hanna Schodterer, who deals with the situation around creating both works; she compares and analyses (SCHODTERER, op. cit.).

57 PEGAH, op. cit., pp. 188-189.

58 „Vom 16. März 1741, einem Donnerstag, datiert die letzte Notiz, die Bioni erwähnt: „Auch hat Bioni Mich auf den Morgenden Abend Zu einer Music eingeladen" (PEGAH, op. cit., p. 189).

59 The last reference about Bioni in opera bibliography is connected with the pasticcio Siroe re di Persia, 


\section{Bioni's work}

Bioni became famous primarily as an opera composer. It is known from the sources that he is the author of 35 operatic works. ${ }^{60}$ However, only the opera Issipile, the serenata La pace fra la virtù e la bellezza, 23 arias and 1 duet from the opera Andromaca ${ }^{61}$ and the overture from the opera Orlando furioso ${ }^{62}$ have been preserved. Jana Spáčilová has newly identified four arias deposited in German Schwerin as arias from Bioni's opera Endimione. ${ }^{63}$ Apart from operatic works, Bioni is also the author of other compositional genres (duet, mass, cantata). ${ }^{64}$ From altogether 23 preserved compositions of various genres (RISM at present files 18), ${ }^{65} 7$ are deposited in Czech archives. ${ }^{66}$ Three compositions are deposited in Prague (2 sacred arias and an overture D major), ${ }^{67}$ and four compositions in Kroměříž.

\section{Bioni's compositions deposited in the music archive of the Archdiocesan Museum in Kroměříž}

In the music archive of the Archdiocesan Museum in Kroměříž there are three Bioni cantatas and one aria. The compositions belong to "the original chateau collection" (Původní zámecká sbírka) and in world musicological literature there are no references to them. In Czech musicological literature, they are first mentioned in Pazdírek's music dictionary of 1937, where the entry about Bioni was created by Brno musicologist Gracian Černušák. ${ }^{68}$ Apart from the diploma thesis written by the author of this study ${ }^{69}$, the existence of Bioni's Kroměříž compositions have been noticed by Jana Spáčilová. ${ }^{70}$

introduced in 1767 in the summer exhibition at Brunswick (Braunschweige Sommermesse) with arias by Bioni, Händel, Vinci, Wagenseil, Hasse and Vivaldi (BRISTIGER - STROHM, op. cit., p. 77).

60 See ČERNÁ, op. cit., pp. 158-159 (Appendix 1: Bioni’s opera works). In the table there is opera Udine, which is a mistake and opera I cacciatori feriti d'amore is missing.

61 PL-KÓ, BK 1669; The opera was discovered by Polish musicologist Michał Bristiger (BRISTIGER, Michal: „Liberta, marito e troni fur miei beni...“ - odzyskana „L’Andromaca“ Antonio Bioniego (1730). In týž: Myśl muzyczna: studia wybrane. Warszawa: Instytut Sztuki Polskiej Akademii Nauk, 2001, pp. 289-296). In 2005 there was a world opera's second run in Kuks (http://www.pavlafrassova.cz/clanky/101-andromache or http:// www.bohadlo.cz/stan/kuks/2005.htm). Other literature: WEGGRZYN - KLISOWSKA, op. cit., pp. 100-102, BRISTIGER - STROHM, op. cit.

62 B-Bc, 34108; GB-Ob, Ms. Mus. e. 36.

63 D-SWl, Mus.4721; SPÁČILOVÁ, 2016, op. cit., pp. 161-162.

64 For more details see ČERNÁ, op. cit., p. 160 (Appendix 2b: Bioni's compositions preserved abroad).

65 RISM. Online Catalogue of Musical Sources. [online]. Bioni, Antonio [cit. 2017-09-13]. Available from: http://www.rism.info/en/service/opac-search.html.

66 See ČERNÁ, op. cit., p. 159 (Appendix 2a: Bioni’s compositions preserved in the Czech Republic).

67 Aria Pulchra Jesu Cordis Stella/Gemma - CZ-Pu, 59R4501; aria Exulte coelum plaude jubila (Aria de Nomine Jesu aut pro omni Tempore) - CZ-Pnm, Hr 372; Ouvertura D dur - CZ-Pnm, XXXIV C 218. 68 ČERNUŠÁK, Gracian. Bioni, Antonio. Pazdirkưv hudebni slovnik naučný. Část osobní. II., Svazek prvý. A-K. / redaktoři Gr. Černušák a Vlad. Helfert. Brno: Nákladem Ol. Pazdírka, 1937, p. 80. However it is stated here that in the collection there are three arias and cantata Innocente by Bioni.

69 VEVERKOVÁ, 2009, op. cit. 
All three cantatas consist of two da capo arias connected by recitative. They are written for soprano, string instruments and basso continuo.

1) cantata $S$ non poss'io (with recitative semplice) n $^{71}$

2) cantata Innocente è il mio martire (with recitative con stromenti) ${ }^{72}$

3) cantata $\mathrm{Se}$ non $\mathrm{ti}$ moro à lato (with recitative con stromenti) ${ }^{73}$

The cantatas show the same hand-writing, they are written on the same paper, and are identical in format, size and ordering of parts. The paper also preserves, apart from one exception, ${ }^{74}$ the same watermarks - the character of Justice, a rectangle with letters $\mathrm{W}$ M S, a heart with an anchor and letters I, C, T, and a leaping stag with antlers. ${ }^{75}$ These cantatas are evidently related by these signs and without doubt share the same provenance and the same date. However, the provenance and the copyist's hand have not been ascertained so far as well as the cantatas' dating. ${ }^{76}$ In the case of the cantata Se non $t i$ moro à lato must be noted that the text of the first aria from this cantata is taken from the Metastasio's libretto Adriano in Siria (1732, Vienna, I/15).$^{77}$

Entirely different from the above mentioned cantatas is the aria De tanti fidi amanti. ${ }^{78}$ It is a da capo aria for tenor, string instruments and basso continuo. This aria has a different hand-writing, as well as watermarks (half-moons and letters A, Z, between which is a shamrock) and colour of the paper. The dating and original provenance are likewise unknown.

In connection with specifying the provenance and dating there appears to be a question as to how the cantatas and the aria came to Kroměříz archive. ${ }^{79}$ One hypothesis arises from Bioni's biographical data. As stated above, between 1734 and 1738 there is no reliable information about Bioni. It is possible that the cantatas might have been written for the Bishop of Olomouc, Wolfgang Hannibal von Schrattenbach (died 1738). Since at that time Bioni did not have a permanent position, the bishop might have asked

70 SPÁČILOVÁ, 2015, op., cit., p. 98.

71 CZ-KRa, A 4101 (former sign. V.B.9.).

72 CZ-KRa, A 4102 (former sign. V.B.10.).

73 CZ-KRa, A 4103 (former sign. V.B.11.).

74 It is a filigree with a stag, which in the cantata Se non ti moro à lato also has an ornamented shield with letters $\mathrm{P}$ and $\mathrm{M}$.

75 For more details see VEVERKOVÁ, 2009, op. cit., pp. 30-32.

76 In the archive of the Prague Conservatory of music there are modern copies of Bioni's Kroměřiz compositions, deposited under book numbers A-I-R 553, A-I-R 554, A-I-R 555, A-I-R 556 (the author's attention to this fact was drawn by Robert Hugo). The author of the copies is Jaroslav Krupka (1893-1929) who worked at Prague Conservatory as a professor of music and archivist since 1919.

77 This opera was performed in 1737 in Vyškov under the name J. A. Hasse. In fact, it was a pasticcio. For more details see SPÁČILOVÁ, Jana. Hudba na dvoře olomouckého biskupa Schrattenbacha (1711-1738). Př́spěvek k libretistice barokni opery a oratoria. Dissertation thesis. Brno: Faculty of Arts, MU, 2006, pp. 118-120. My thanks for bringing my attention to the opera Adriano in Siria belong to Ms. Jana Spáčilová.

78 CZ-Kra, A 4100 (former sign. V.B.8.).

79 Ibid, p. 33. 
for a job of a musician in this way. Apart from the deposit of Bioni's compositions in Kroměříž no other relation to this town has been proved, but the possibility of an exceptional status, which Italian artists had at Bishop Schrattenbach's court, is highly likely. ${ }^{80}$ Hopefully this question will be answered in the course of further research.

\section{The cantata Innocente è il mio martire - musical analysis}

For the analysis through which Bioni's compositional style will be demonstrated, we have chosen the cantata Innocente è il mio martire, whose score the author created for her diploma thesis. ${ }^{81}$

The cantata is written for soprano, two violins, viola and continuo. It consists of two da capo arias and recitative con stromenti. The aria Innocente $\grave{e}$ il mio martire is 73 bars long, the recitative contains 26 bars, and the aria Crudo ciel contains 169 bars. The manuscript of the cantata has 19 sheets altogether and consists of three parts - the cover with the composition's title and composer's name and signature, then a particello for vocal and basso continuo, and individual instrumental parts.

The anonymous text of the cantata is in its structure and contents typical for the time of its origin; it was the time when secular cantata creation was very similar to operatic creation, so in fact it follows the same rules. For recitative and aria Italian meter is very important. Recitative is created by non-rhymed verses which have 7 or 11 syllables; in arias all the verses are rhymed according to a certain rhyme structure. To be concrete, in the first aria the structure is A A B A A A C B (number of syllables - 88788867 ). In the text of the cantata there are several grammar and semantic mistakes that would not have been made by a native Italian, therefore the possibility that it is Bioni's autograph can be excluded. The copyist obviously came from the regions beyond the Alps, most probably from the Habsburg monarchy. ${ }^{82}$

The vocal part ranges from $\mathrm{d}^{1}$ to $\mathrm{a}^{2}$, which is a common soprano range. From the technical point of view, coloratura passages are considered especially difficult. Concerning ornaments, in several places there are trills and appoggiaturas. To sum it up, the cantata is for technically advanced singers.

\section{Aria Innocente è il mio martire}

Innocente è il mio martire

Che con pena di morire

L'alma mia viver non sà.

Tutto pieno di terrore

Spasimato sento il core,

80 SPÁČILOVÁ, 2015, op. cit., p. 98. So far evidence of contact with Bishop Schrattenbach is not known. In Jana Spáčilová's dissertation thesis, which deals with music at his court, Bioni's name is not mentioned. (SPÁČILOVÁ, 2006, op. cit.)

81 VEVERKOVÁ, op. cit.

82 The Wrocław origin of cantatas is discussed in Jana Spáčilová’s study - SPÁČILOVÁ 2015, op. cit., p. 98. 
Dà timore, da dolore

Qual pena che sia

Più dir non sò, nò, non sò.

It is a two-part da capo aria in which parts $\mathrm{A}$ and $\mathrm{B}$ are in distinctive disproportion in the number of bars (part $\mathrm{A}=60$ bars, part $\mathrm{B}=13$ bars). The aria is composed in $\mathrm{D}$ major. According to Johann Mattheson, ${ }^{83}$ the key of D major is rather sharp, stubborn and appropriate for noisy, merry, military and encouraging affairs ${ }^{84}$ However, the text of the aria expresses pain and suffering, which is not too much in accordance with the key characteristics.

The aria is opened by an instrumental ritornello in $\mathrm{D}$ major which introduces basic motives that are repeated during the whole of part A. The most distinctive is a motive of broken descending and ascending five- and six-three chords in sixteenth-note triplets; this is one of the characteristic features of galant style in opera. ${ }^{85}$ The main melody of the introductory ritornello is assigned to the first and second violin parts which proceed in unison. Viola and basso continuo play in the same rhythmic values and have an accompanying function.

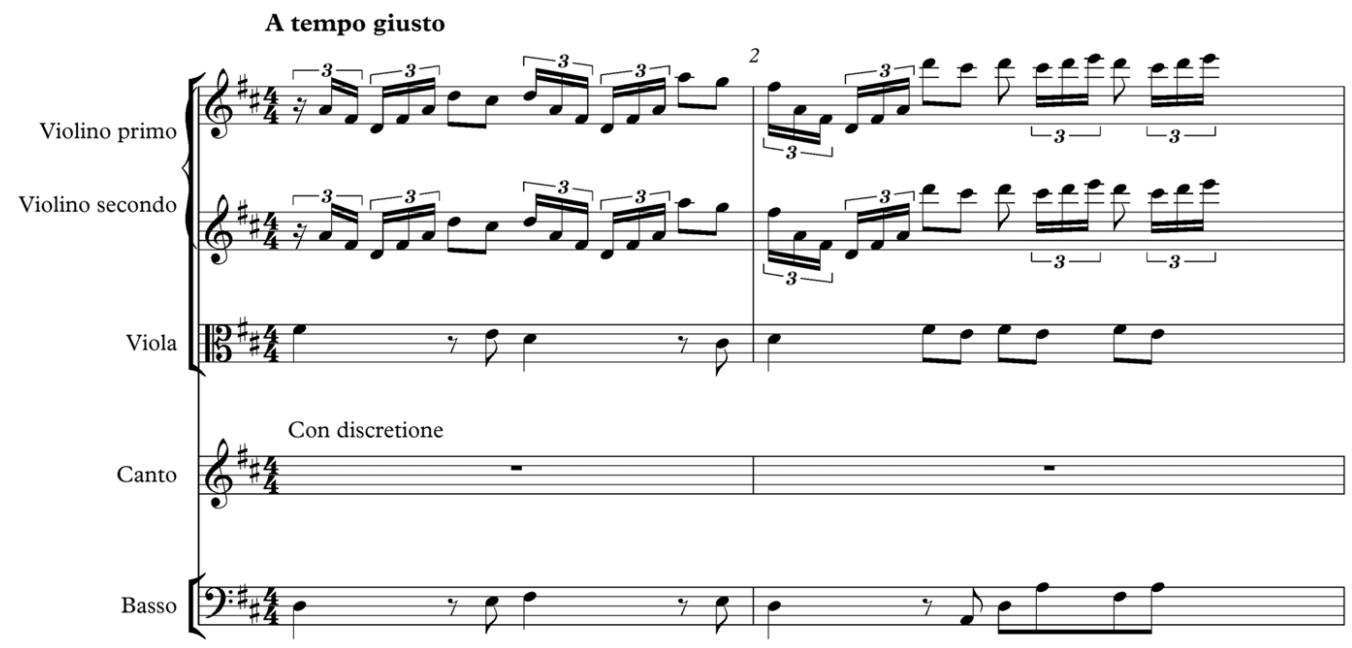

Example No. 1 - introductory instrumental ritornello ${ }^{86}$

83 MATTHESON, Johann. Die drei Orchestre-Schriften. I, Das neu-eröffnete Orchestre. 3. Aufl. Laaber: Laaber, 2007, pp. 242-243.

84 „D. dur. ist von Natur etwas scharff und eigensinnig; zum Lermen / lustigen / kriegerischen / und auffmunternden Sachen wol am allerbequemsten; doch wird zugleich niemand in Abrede seyn / daß nicht auch dieser harte Tohn [...] / gar artige und frembde Anleitung zu delicaten Sachen geben könne. "Ibid, pp. 242-243.

85 PERUTKOVÁ, Jana. Problematika galantního stylu ve světle dobových pramenů (s bližším zaměřením na hudebně dramatickou tvorbu). Musicologica Brunensia, 2011, vol. 46, Nr. 1., pp. 127-139.

86 I would like to thank Pavel Trkan for helping me to create the music examples. 
In bar 10 the vocal part begins and is accompanied by the first violin, viola and basso continuo which play repeated pulsating eighth notes (Trommelbass) often used by composers showing their first released works in Napoli. The second violin plays the triplet motive from the ritornello. After the first verse (Innocente è il mio martire) there comes a short instrumental ritornello - again the introductory triplet theme in D major.

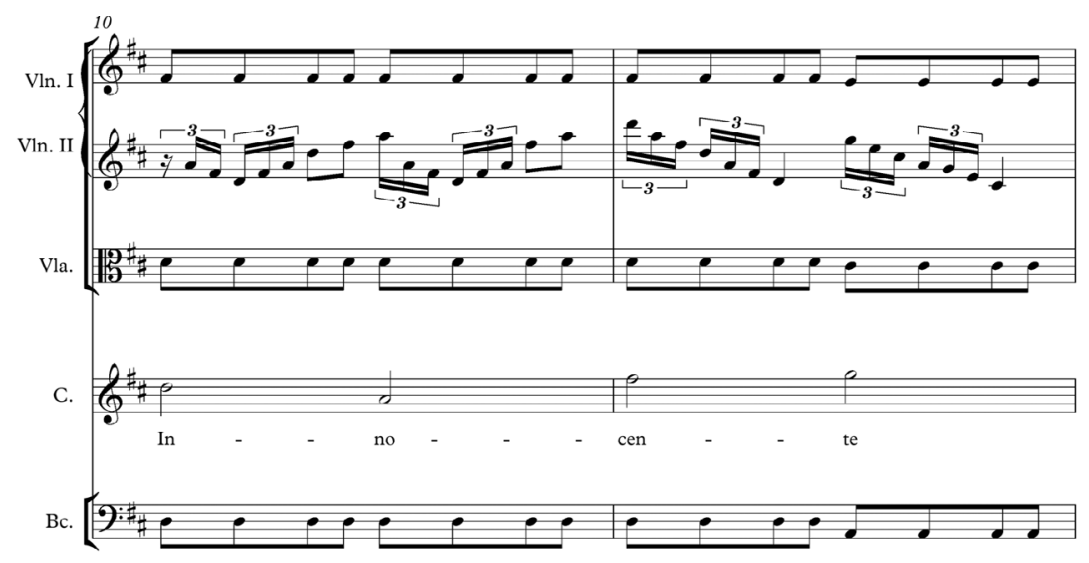

Example No. 2 - beginning of the vocal part

In bars 15-18 two remaining verses are heard (Che con pena di morire, L'alma mia viver non sà) with the above mentioned accompaniment. The main melody is assigned to the second violin without basso continuo accompaniment so that the importance of the text can emerge even more (after all my soul cannot live with the deadly pain). The lyrics pena di morire (deadly pain) are harmoniously highlighted by minor keys - e minor and b minor (bars 15-16).

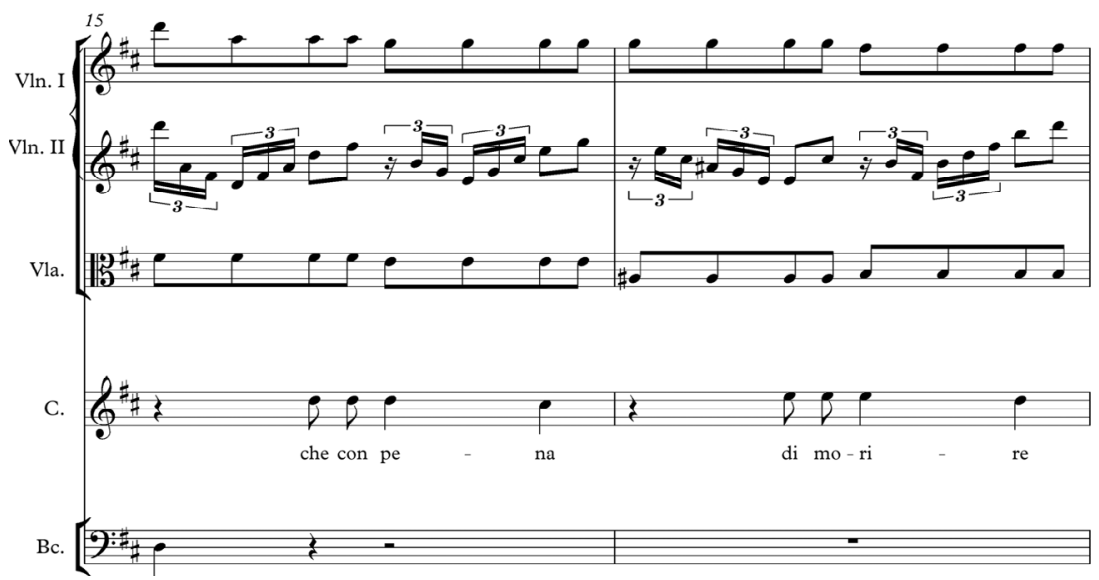

Example No. 3 - setting text "che con pena di morire" to music 
In bars 19-20 the verse l'alma mia viver non sà (my soul cannot live) is repeated; from the point of view of affect, this can be considered the key verse of the whole aria. To reflect the meaning of these words, the melody is descending and uses syncopation. The vocal part is in unison with the first violin.

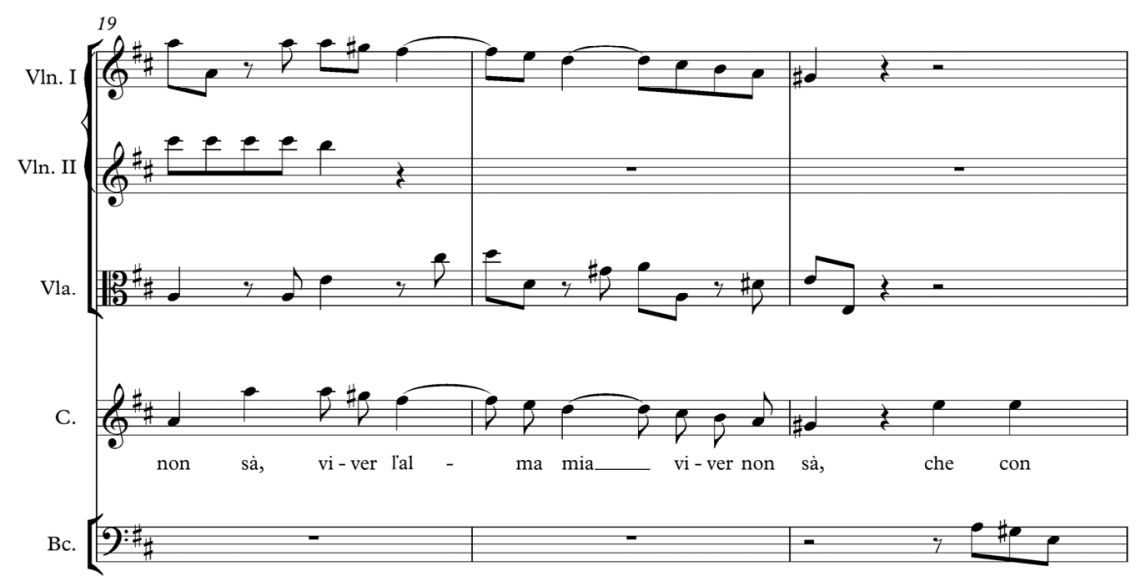

Example No. 4 - setting text "I'alma mia viver non sà" to music

Then a repetition of the two last verses follows, while the verse l'alma mia viver non sà is repeated again. In bar 25 there is a great intervallic skip ( $\left.\mathrm{e}^{1}-\mathrm{g}^{2} \operatorname{sharp}\right)$ - exclamatio.

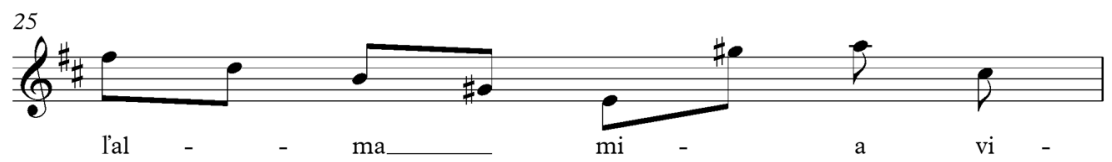

Example No. 5 - exclamatio on the word "mia"

The word l'alma (soul) in bars $28-30$ is highlighted by ascending coloratura composed of triplets. The ascending direction of the coloratura undoubtedly expresses the meaning of the word "soul" (meaning "to rise above the body").

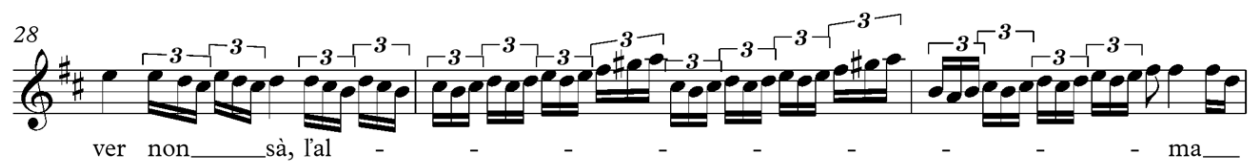

Example No. 6 - coloratura on the word "l'alma"

The first part of piece A is divided from the second part again by the motive from the introductory ritornello in A major. After that the whole text of piece A is sung more or less with the motives from the first part. However, the vocal part is more orna- 
mental (ornaments, faster values, inserted tones). In bar 36 there is exclamatio on the word martire.

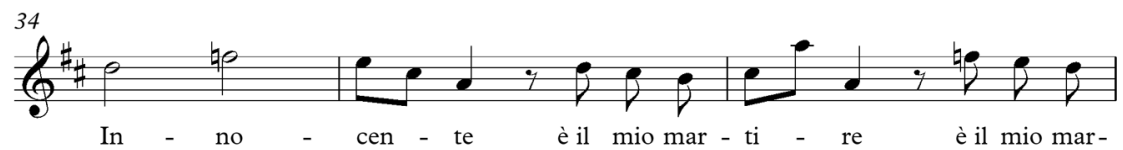

Example No. 7 - exclamatio on the word "martire"

In bar 38 there are appoggiaturas which complete the text pena di morire (fatal pain) with elements characteristic for lament, crying, voice trembling etc.

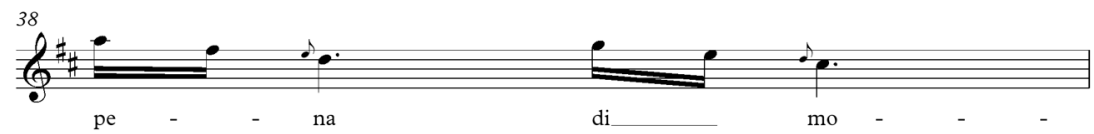

Example No. 8 - appoggiaturas on words "pena di morire"

In the following bars there is a large coloratura passage composed of sixteen triplets and using trills on the word non sà (it cannot manage). The coloratura is accompanied only by basso continuo, which makes it even more distinctive.

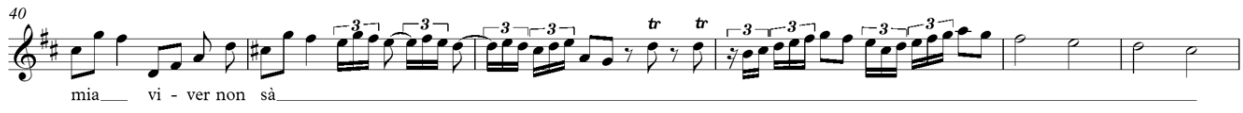

Example No. 9 - coloratura on word "non sà"

In part $\mathrm{B}$, which is in the relative key of $\mathrm{b}$ minor (according to Mattheson, a bizarre, cheerless and melancholic key), ${ }^{87}$ the vocal part starts with the accompaniment of the first violin, viola and basso continuo, which move in eighth notes. The second violin plays a moderately changed triplet motive from the previous part. Starting from the words di terrore (bar 63) the accompaniment strikingly changes. This change without doubt relates to the text di terrore, spasimato sento il core, dà timore, da dolore (I can feel my heart tormented with horror; it causes fear, it causes pain).

87 „H.moll. ist bizarre, unlustig und melancholish; deswegen er auch selten zum Vorschein kommet / und mag solches vielleicht die Ursache seyn / warum ihn die Alten aus ihren Clöstern und Zellen so gar verbannet haben / daß sie sich auch seiner nicht einmahl erinnern mögen. "MATTHESON, 2007, op. cit., pp. 250-251. 


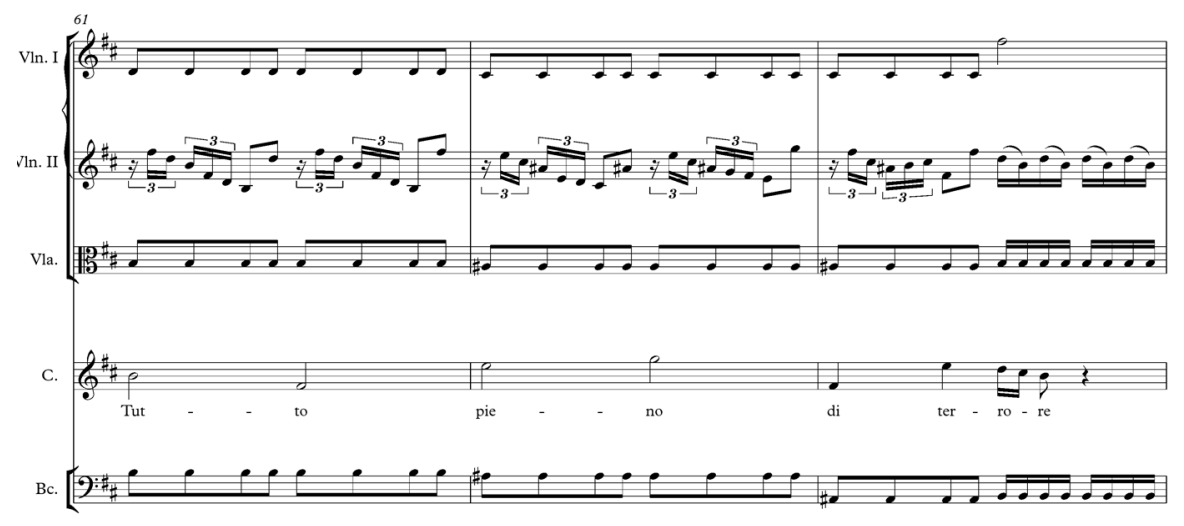

Example No. 10 - beginning of part B with the change on the word "di terrore"

The viola and second violin play sixteenth-note figures based on broken intervals in very fast tempo (bars 65-67). The tension and tragic nature are escalated by ostinato accompaniment in the basso continuo. The meaning of the text is underlined by modulations (from $b$ minor to $F$ sharp major, then to D major and $G$ major and finally to A major and $\mathrm{D}$ major) and by including descending chromaticism in the first violin part (bars 66-67). After the word dolore (pain) the first violin plays ascending tirata (bar 68).

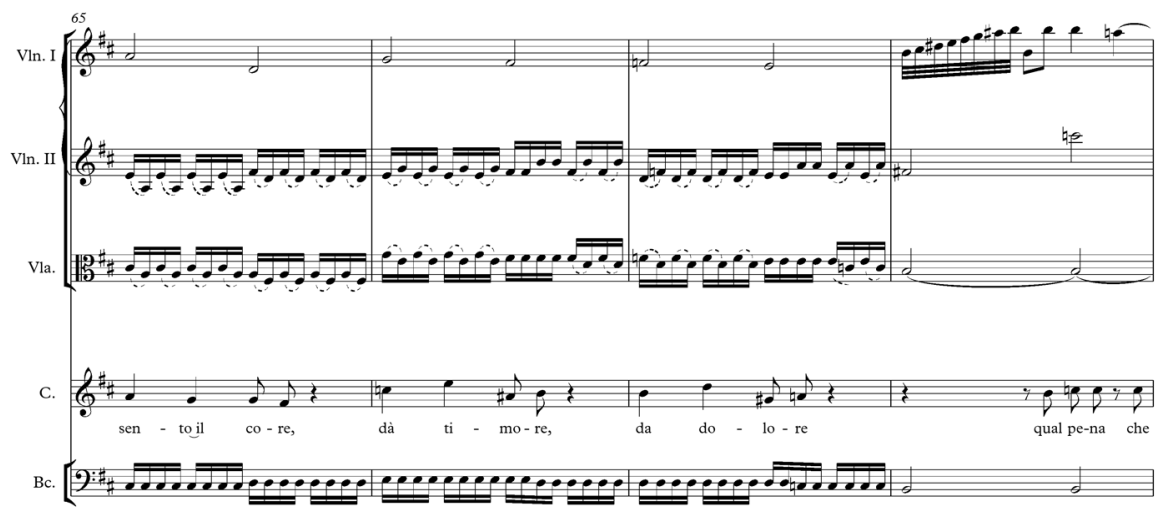

Example No. 11 - ostinato accompaniment by basso continuo, chromaticism in the part of the first violin, tirata

The closing of part B brings a general mollification of the music. The whole of part B is, with regard to the text, highly dramatic and thus it contrasts with part A. 


\section{Recitative}

Almen dormendo, oh Dei,

Concedetemi, si, per picciol che sia

Riposo all'alma mia.

[Che] languido il volto, pallido il labbro,

E poi confuso il core

L'alma mia allor cosi vivendo more.

Se volgo agl'occhi il sonno,

Larve, [e] terrori tremo,

Furie di Lete io veggio, e mi spavento:

Povero afflitto core,

Soccorer non ti posso,

E pur penare io deggio.

The recitative con stromenti has altogether 26 bars, starting in $g$ minor and staying in minor mode. In bars 1-11 the vocal part is accompanied only by basso continuo and from the $11^{\text {th }}$ bar the orchestra starts playing. Right in the first and second bars there is an exclamatio on words oh Dei.

C.

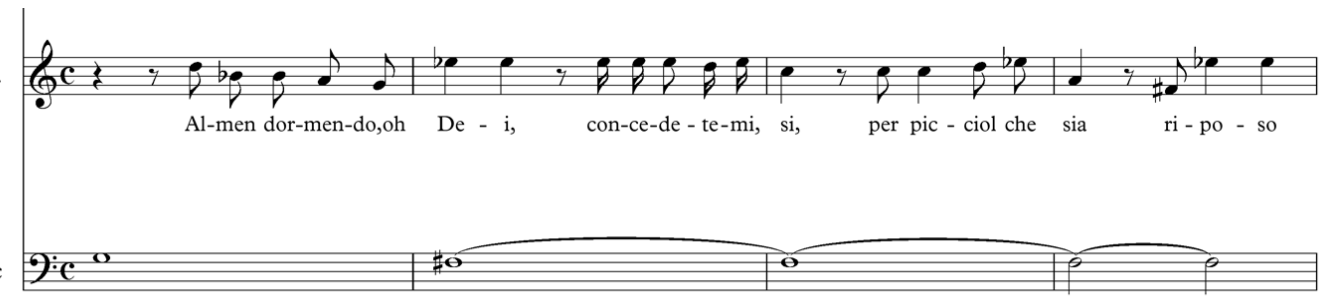

Example No. 12 - beginning of the recitative, exclamatio on words "oh Dei"

Then, in the following bars there are sixth, seventh and octave leaps in the vocal part; some of the sevenths are diminished (e. g. bar 4 - diminished seventh). From bar 11 the violins play in unison a broken sequence of descending chords and inversions in B-flat major. The dramatic climax of the whole recitative comes in bars 14-17 during the words larve, terrori tremo (I am shuddering when seeing horrors and phantoms). Then, in bars 15-17 there are dissonant skips both up and down (saltus duriusculus). In addition, all of this part is intensified by chromatic movement in the first and second violins, putting stress on the word tremo (I am shuddering). 


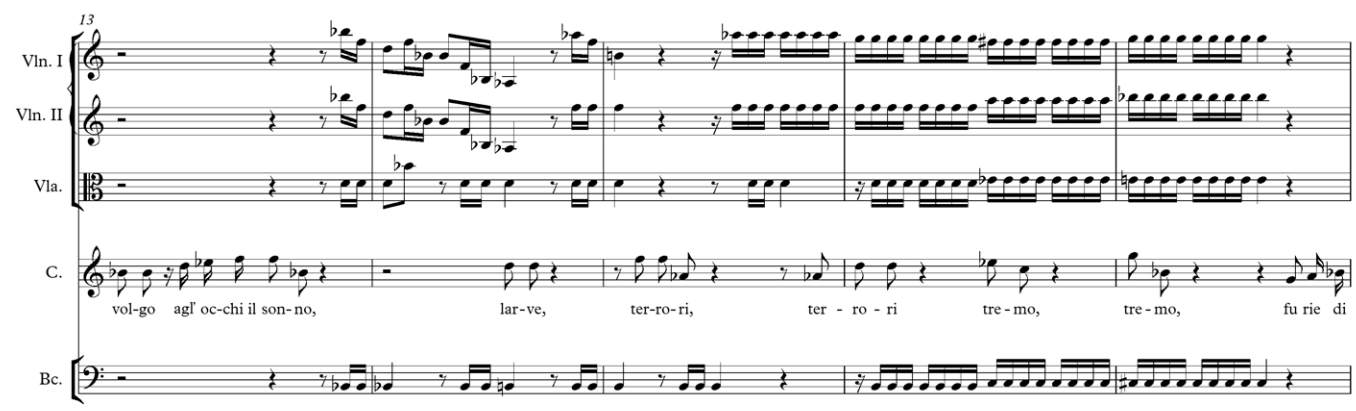

Example No. 13 - dramatic climax on words "larve, terrori tremo", saltus duriusculus, chromatics

Between bars 17 and 18 in the vocal part there is an interval of a diminished fourth downward (saltus duriusculus) on the words di Lete, which underlines the meaning of this word (Lete - chthonian river Léthé).

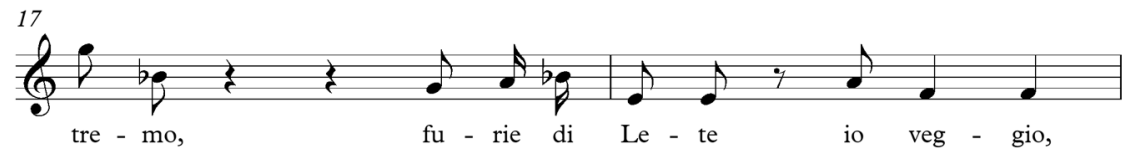

Example No. 14 - saltus duriusculus on words "di Lete"

On the word spavento (I dread) there is a descending sixteenth-note coloratura with accompaniment only of basso continuo. In addition, the coloratura ends with a trill indicating trembling, which emphasizes the onomatopoeic potential of the discussed word even more (bars 19-20).

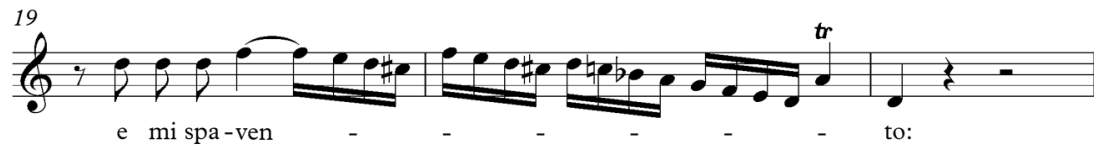

Example No. 15 - coloratura on word "spavento"

Then the orchestra starts playing a variation on the above mentioned motive in B-flat major with chromaticism (bars 21-22). 


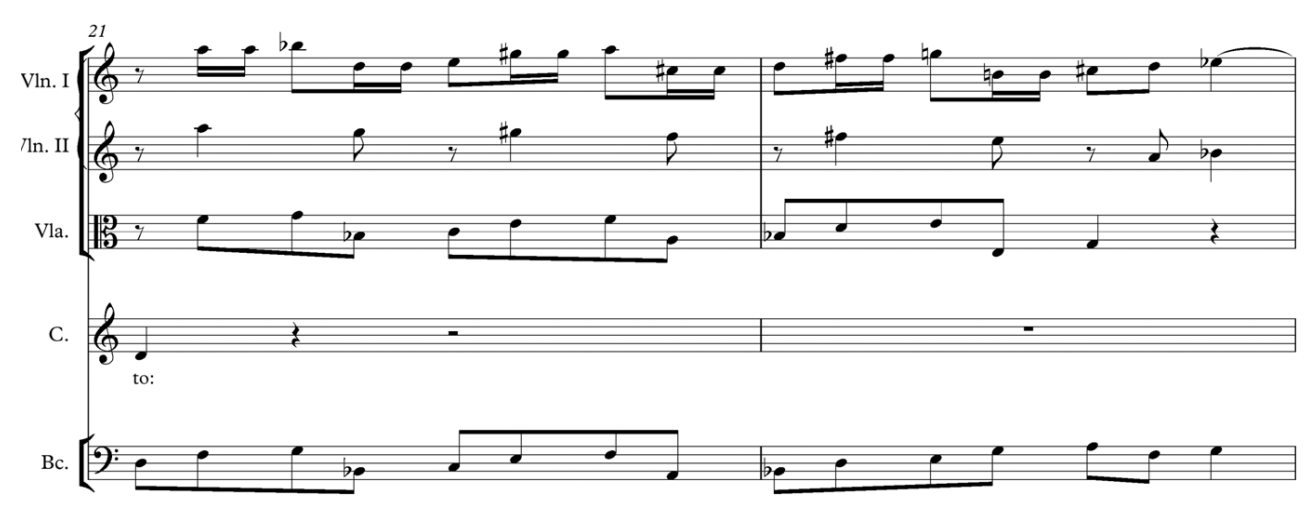

Example No. 16 - chromaticism in bars 21-22

After that comes a softening, with chords held by individual instruments, and a general sense of conciliation which results from the text - Soccorer non ti posso, e pur penare io deggio (I can't help you and yet I have to suffer). The recitative thus ends apologetically in $\mathrm{G}$ major, subdominant to the following $\mathrm{D}$ major.

\section{Aria Crudo Ciel}

Crudo/giusto Ciel, mà dimmi quando,

Del mio cor che stà penando,

Se tu avrai di lui pietà.

Troppo acerbe le mie pene,

Quanto dure le catene,

Se non conforti l'alma

Che fuor di me sen stà.

This aria, with 169 bars, is the longest part of the whole cantata. Part A is in strong disproportion with part $\mathrm{B}$. The aria is again in $\mathrm{D}$ major. The character is moderate and serene. The beginning of the aria is imitative. Its motive is based on an eighth-note ostinato in a chromatically descending sequence. In bar 4 the first violin plays figurations in dotted rhythm which might remind one of sighs (Seufzer). The general mood of the introductory ritornello corresponds with the text and meaning of the whole aria. 


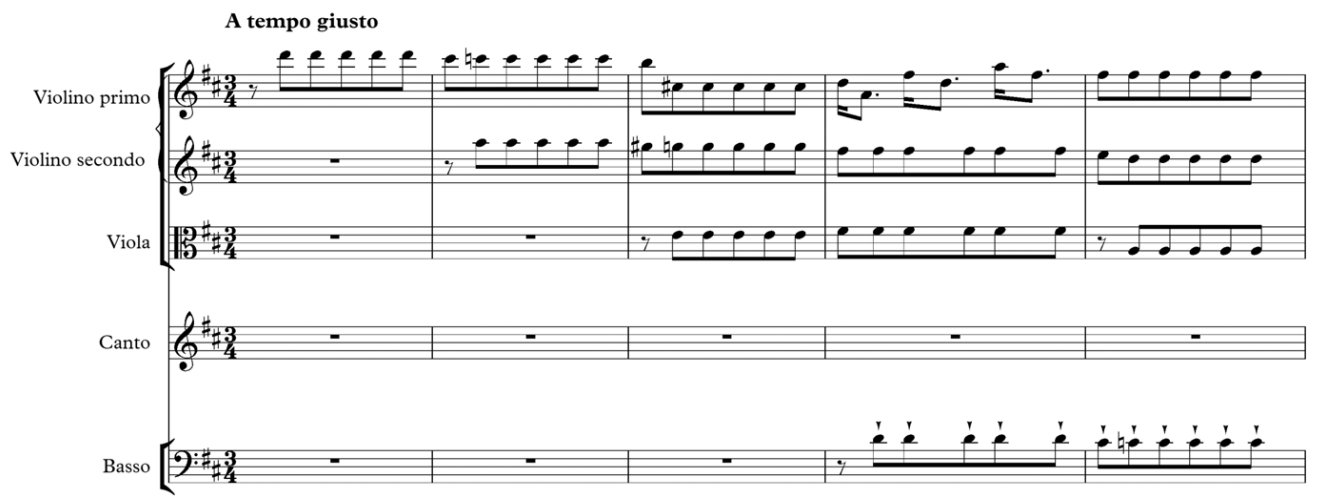

Example No. 17 - beginning of the aria

In bars 9-10 only violins play in unison a broken D-major chord in slow rhythmic values. Starting at bar 11, viola and basso continuo join in. This motive then appears with the entrance of the vocal part. In bar 16 the introductory ostinato motive starts again, and in bars 22-27 it finishes with a broken D-major chord. The vocal part enters without any accompaniment in bar 28 on a broken, ascending D-major five-three chord, with the text Crudo Ciel (cruel heaven).

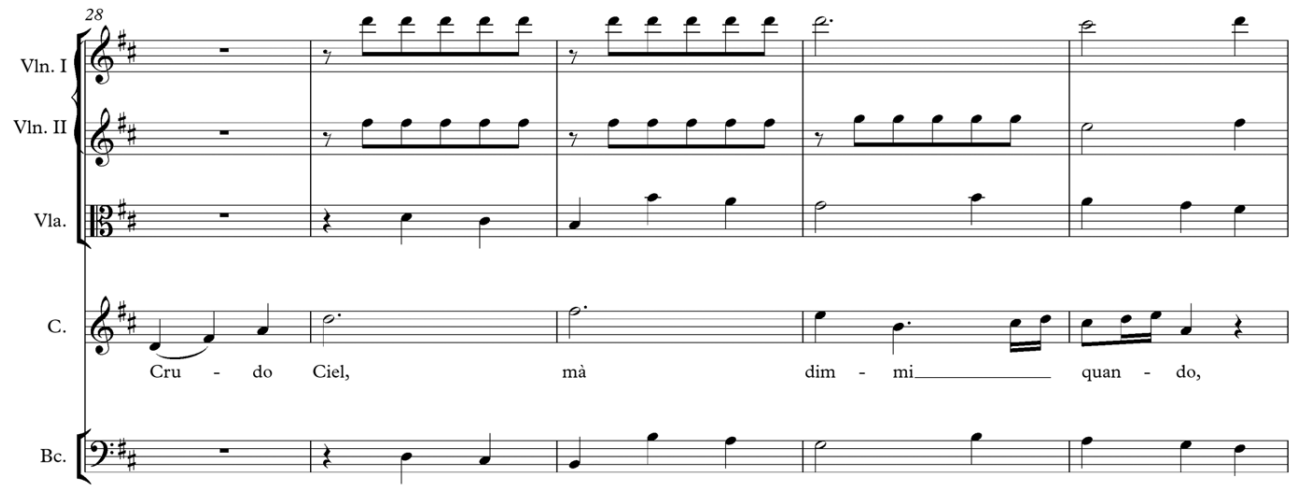

Example No. 18 - entrance of the vocal part

In bars 44-45 on the words giusto Ciel (just heaven) all the parts are written in unison and again the ascending broken five-three chord is used (movement upwards, to heaven). 


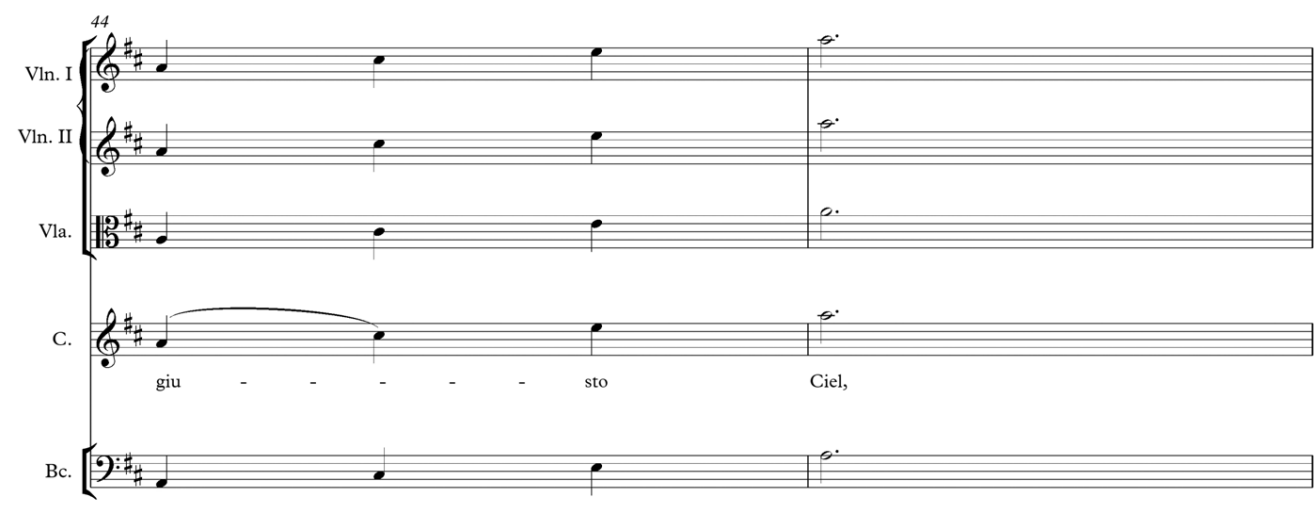

Example No. 19 - unison in all the parts

In the following bars (46-55), when the first verse is repeated (however, instead of crudo Ciel we hear giusto $\mathrm{Ciel}$ ), the vocal part proceeds in quarter-note values in unison with the second violin. Basso continuo goes up in semitones in minims, in the same way as the viola. In the vocal part and second violin there are syncopes and melodic movement, which is repeated more times and is posed on the next scale degree (climax, bars 49-55). On the word penando (it suffers) there is a short coloratura (bars 53-55), which is accompanied by a chromatic sequence downwards in the first violin.

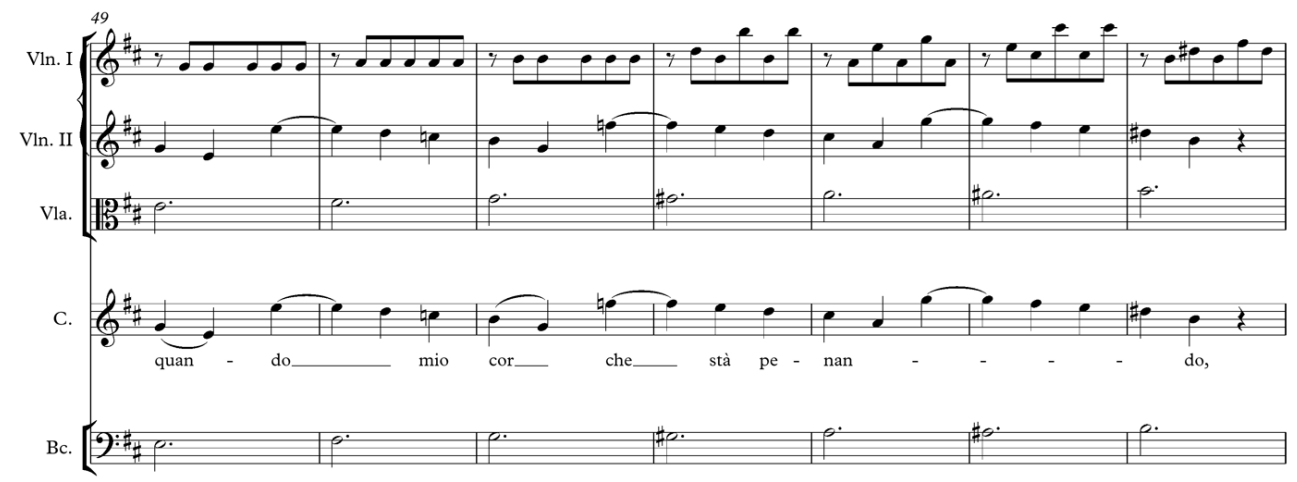

Example No. 20 - climax (bars 49 - 55), coloratura on the word "penando"

The text is consequently repeated and on the word penando coloratura is used again - this time more extensively (bars 59-63).

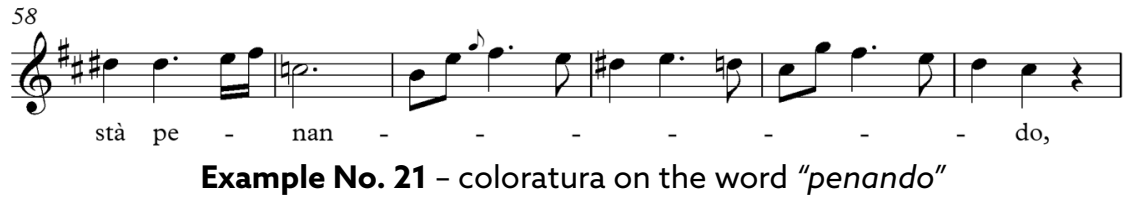


Then comes the verse se tu aurai di lui pietà (I wonder if you feel for him) when the word pietà (compassion) is stressed; on this word the first violin and the vocal part are in unison (bars 68-69).

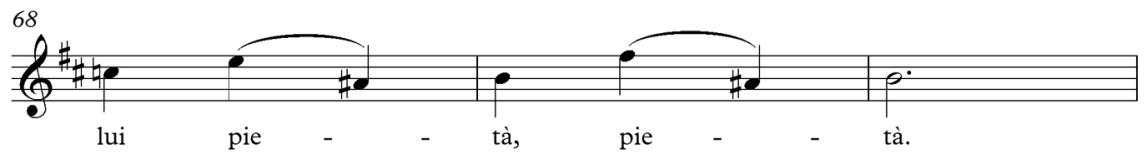

Example No. 22 - setting the word "pietà" on music

The first part of part A is closed with a ritornello which introduces a new triplet motive (bars 70-72) that gradually changes in an ostinato the melody of the introductory ritornello. The second part of part A starts at bar 80 and the previous text is repeated. In bars 87-103 there is again coloratura on the word penando with ostinato accompaniment by the instruments; this coloratura is very extensive (altogether 17 bars). It is composed of several rhythmic and melodic figures that are repeated. At the end of the coloratura there are "sighs" again (bar 102).

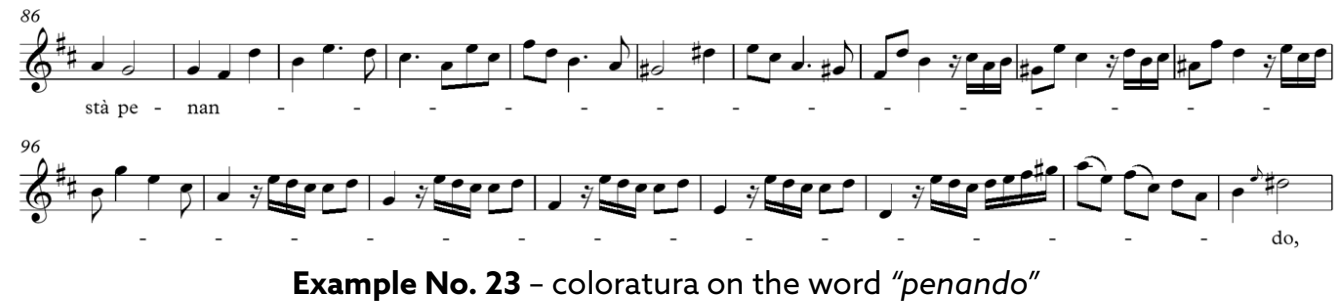

From bar 107 the coloratura is on the word pietà (compassion). In bars 109-111 of the vocal part there is a descending melody (catabasis) with triplets, after which there is a crotchet with an appogiatura.

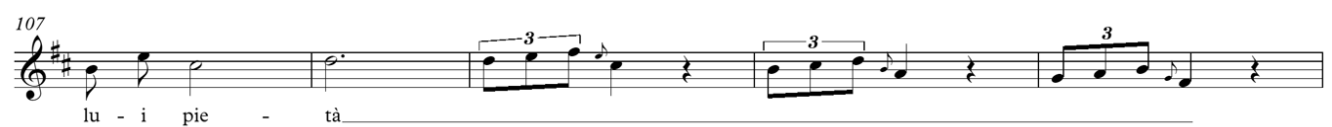

Example No. 24 - coloratura on the word "pietà", catabasis in bars 109-111

After that the introductory ritornello repeats and part A finishes.

Part B is again composed in the relative key of $\mathrm{b}$ minor (from bar 143). The violin brings in a new motive - broken octaves which are taken over from the first violin by the second violin, lower by one third. In this way they hold a dialogue. The viola and basso continuo markedly join the second violin in eighth-note values and thus they underline the importance of the words acerbe (bitter), pene (torment), dure (hard) and catene (chains), in bars 144, 146, 148, 150. At the beginning of the vocal part there is again a descending melody (catabasis). 


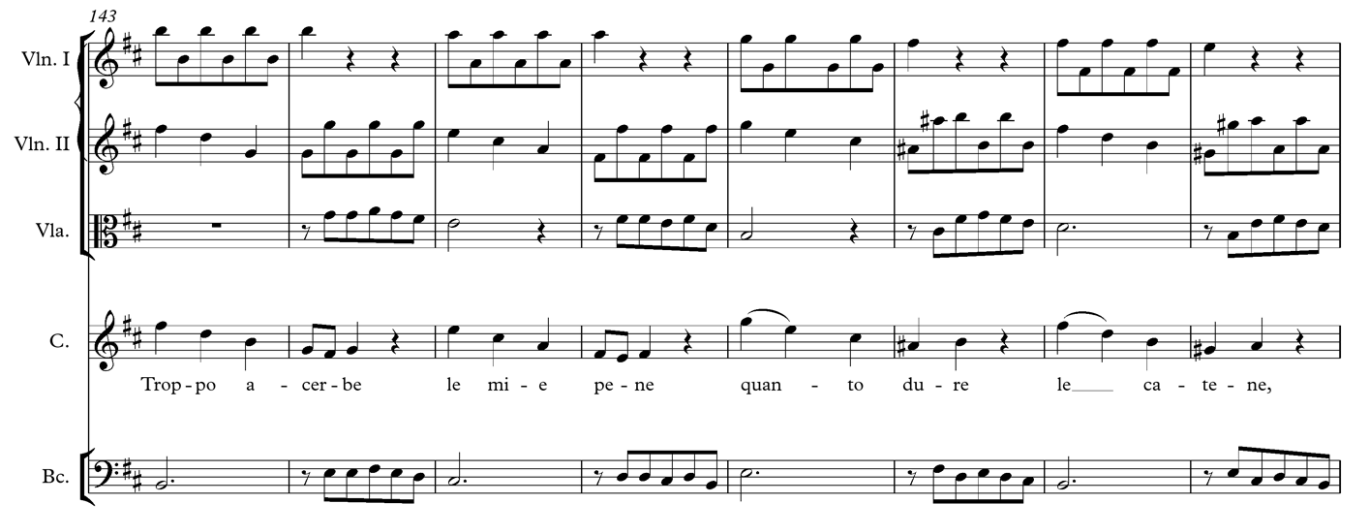

Example No. 25 - beginning of part B

In part B the text is sung syllabically and only on the last syllable, stà, there appears an extensive coloratura in which the vocal part is accompanied by the violin, first in thirds (bars 156-160) and then in unison (bars 161-165). The coloratura starts in bar 156 where there is a dissonant skip. In the violin part, in bars 156-159 mournful chromatic steps appear (passus duriusculus).

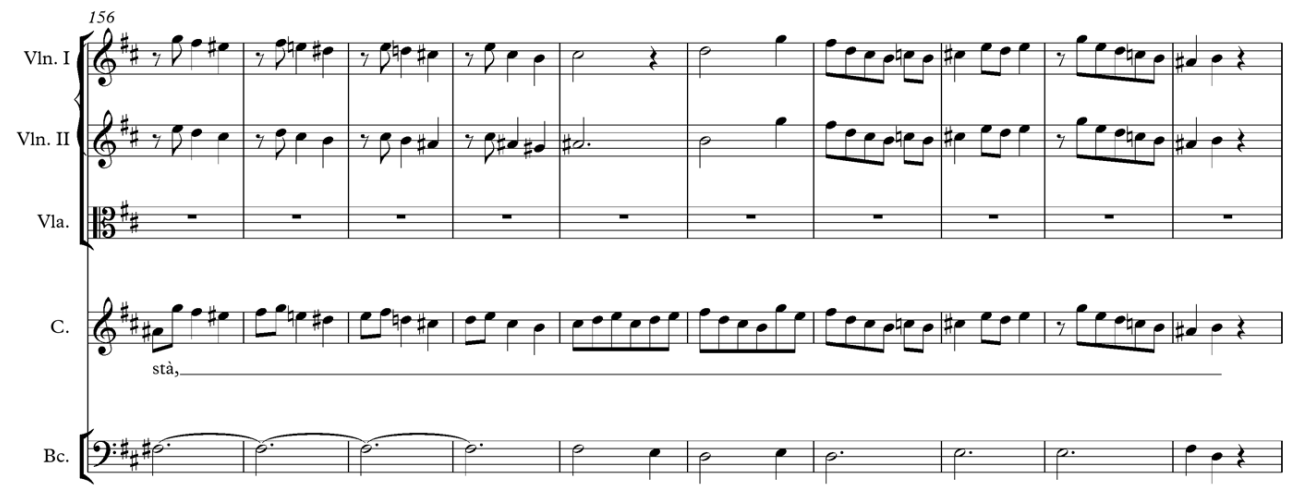

Example No. 26 - coloratura on the word "stà", passus duriusculus in the violin part

Part B finishes with a double repetition of the verse che fuor di me sen stà (the one who is delirious) which is set to music by a motive that uses dotted rhythms (bars 166-168). The violin sounds again in unison with the vocal part, and the closing key of $b$ minor, together with a moderate tempo and more or less tranquil progression, implies a feeling of suffering and pathetic craving for compassion. 


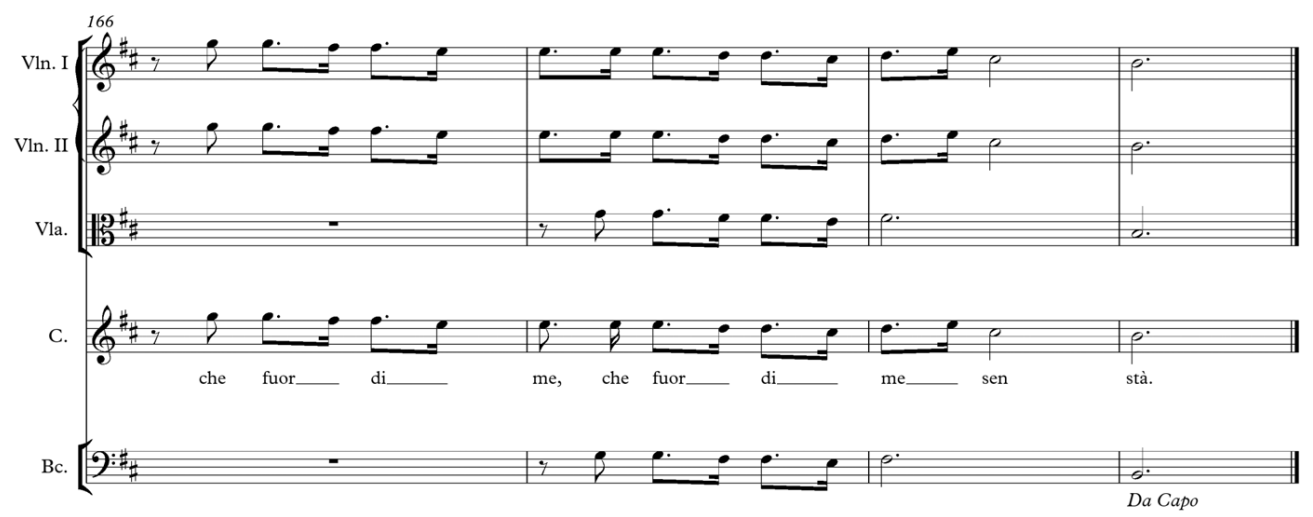

Example No. 27 - closing of the aria

\section{Summary of the musical analysis}

From a formal point of view, this is a cantata composed in the galant style that appears in secular operatic and cantata creations of the $20 \mathrm{~s}$ and especially the $30 \mathrm{~s}$ of the $18^{\text {th }}$ century. ${ }^{88}$ The cantata is written in homophonic structure with the emphasis on vocal virtuosity. Bioni's way of treating the text (i.e., his depiction of individual affects and expression of negative emotions - laments, pain and suffering) and the whole arrangement of the cantata are typical for cantata creation in the first half of the $18^{\text {th }}$ century. Within the scope of further research on Bioni we will create scores of two other cantatas from the Kroměříž collection which share common characteristics and origin with the cantata Innocente è il mio martire. Last but not least, it will be interesting to compare these with Bioni's cantatas archived in German Ansbach. So far we can at least compare the cantata with Bioni's serenata La pace fra la virtù e la bellezza in basic features; the analysis of the serenata can be found in Hanna Schodterer's diploma thesis. ${ }^{89}$ It describes Bioni's compositional style as homophonic and due to clear melodies, pulsating eighth notes (Trommelbass) and broken chords it appears almost as early classicist (Frühklassisch). ${ }^{90}$ The term early classicism in the context of operatic creation by Leonardo Vinci is also used by e.g. Kurt Markström. ${ }^{91}$ We believe that this term acts in secular musical and dramatic art almost as a synonym with the term galant style. As the latter is a period expression, we rather tend to use this term. We identify with Schodterer in her opinion that Bioni's arias are dramatically effective and expressively strong. ${ }^{92}$

\footnotetext{
88 PERUTKOVÁ, 2011, op. cit.

89 SCHODTERER, op. cit.

90 Ibid., p. 113.

91 MARKSTROM, Kurt Sven. The operas of Leonardo Vinci, Napoletano. Opera series, no. 2. Hillsdale - New York: Pendragon Press, 2007.
}

92 SCHODTERER, op. cit., p. 164. 


\section{Conclusion}

This study presents not only a summary of existing research about Antonio Bioni, in whose career and creations we can trace the connectedness of musical centres - Prague, Wrocław, Jaromerřice nad Rokytnou and Vienna - of the first half of the $18^{\text {th }}$ century, but also offers a probe into his compositional technique. Further research will hopefully bring discovery of other Bioni works and additional information about his life especially about the period between his departure from Wrocław and arrival in Vienna (1734-1738), and about his activities after 1741.

\section{Bibliography}

\section{Sources}

Bioni, Antonio. Andromaca (Wrocław 1730), score. PL-KÓ, BK 1669.

Bioni, Antonio. Aria Pulchra Jesu Cordis Stella. CZ-Pu, 59R4501.

Bioni, Antonio. De tanti fidi amanti. CZ-Kra, A 4100 (former sign. V.B.8.).

Bioni, Antonio. Dice Tirsi ch'io son bella, In questo seno io provo, Compatisco quegli amanti, Usignolo che in vale ombroso (Arias from the opera Endimione, Wrocław 1727). D-SWl, Mus.4721.

Bioni, Antonio. Exulte coelum plaude jubila (Aria de Nomine Jesu aut pro omni Tempore). CZ-Pnm, Hr 372.

Bioni, Antonio. Innocente è il mio martire. CZ-KRa, A 4102 (former sign. V.B.10.).

Bioni, Antonio. Innocente è il mio martire (the copy of Jaroslav Krupka). The archive of the Prague Conservatory, A-I-R 553.

Bioni, Antonio. Issipile (Wrocław 1732), score. A-Wgm, IV 27740 (Q1214).

Bioni, Antonio. La pace fra la virtù e la bellezza (Vienna 1739), score. A-Wn, Mus. Hs. 16516.

Bioni, Antonio. Orlando furioso (overture). B-Bc, 34108.

Bioni, Antonio. Orlando furioso (overture). GB-Ob, Ms. Mus. e. 36.

Bioni, Antonio. Ouvertura D dur. CZ-Pnm, XXXIV C 218.

Bioni, Antonio. Se non poss'io. CZ-KRa, A 4101 (former sign.V.B.9.).

Bioni, Antonio. Se non ti moro à lato. CZ-KRa, A 4103 (former sign. V.B.11.).

Metastasio, Pietro - Bioni, Antonio. Issipile (Wrocław 1732), libretto. I-Mb, Racc.dram.5675/002.

Zeno, Apostolo - Bioni, Antonio. Andromaca (Wrocław 1730), libretto. PL-WRu, Yv 984/4

(inv. n. 84836).

[Anonym] - Bioni, Antonio. Die von der Liebe verwundete Jäger (Vienna 1729), libretto. US-CAh, GC7 A100 B750 vol. 114.

[Anonym] - Bioni, Antonio. I cacciatori feriti d'amore (Vienna 1729), libretto. US-CAh, GC7 A100 B750 vol. 123.

[Anonym] - Bioni, Antonio. Il Climene (Udine, 1722), libretto. I-Rn, 35. 6.B.2.5. 


\section{Literature}

BOHADLO, Stanislav. Antonio Denzio. Starši divadlo v českých zemich do konce 18. století. Osobnosti a díla, ed. A. Jakubcová. Praha: Divadelní ústav - Academia, 2007.

BOHADLO, Stanislav. Questenberg a Sporck - oddělené a nezávislé barokní hudební subkultury na Moravě a v Čechách? Musicologica Brunensia, 2011, vol. 46, Nr. 1-2, pp. 15-34.

BOHADLO, Stanislav - JONÁŠOVÁ, Milada. Peruzzi, Antonio Maria. Starši divadlo v českých zemich do konce 18. století. Osobnosti a dila, ed. A. Jakubcová. Praha: Divadelní ústav - Academia, 2007.

BORCHERDT, Hans Heinrich. Geschichte der italienischen Oper in Breslau. Zeitschrift des Vereins für Geschichte Schlesiens. 1910, vol. 44. pp. 18-51.

BRISTIGER, Michal: „Liberta, marito e troni fur miei beni...“ - odzyskana „L'Andromaca“ Antonio Bioniego (1730). In týž: Myśl muzyczna: studia wybrane. Warszawa: Instytut Sztuki Polskiej Akademii Nauk, 2001, pp. 289-296.

BRISTIGER, Michał - STROHM, Reinhard. „Libertà, marito e trono fur miei beni...“: Die wiederentdeckte Andromaca von Antonio Bioni (Breslau 1730). In Opera Subjects and European Relationships [= Italian Opera in Central Europe, 1618-1780, Bd. 3]. DUBOWY, Norbert - HERR, Corinna - ŻÓRAWSKA- WITKOWSKA, Alina (eds.), Berlin: BWV, 2007, pp. 73-109.

ČERNÁ, Zuzana. Antonio Bioni: „operista“ mezi Prahou, Kuksem, Vratislaví, Jaroměřicemi a Vídní. Clavibus unitis, Praha: Nadace pro dějiny kultury ve střední Evropě, vol. 2014, Nr. 3, pp. 151-160.

ČERNUŠÁK, Gracian. Bioni, Antonio. Pazdirkưv hudebni slovnik naučný. Část osobní. II., Svazek prvý. A-K. / redaktoři Gr. Černušák a Vlad. Helfert. Brno: Nákladem Ol. Pazdírka, 1937.

FÉTIS, François Joseph. Bioni Antoine. Biographie universelle des musiciens et bibliographie générale de la musique. Tome premier. Paris: Librairie de Firmin-Didot, 1883.

FREEMAN, E. Daniel. The Opera Theater of Count Franz Anton von Sporck in Prague. Studies in Czech Music 2. Stuyvesant - New York: Pendragon Press, 1992.

FREEMAN, Daniel E. Orlando furioso in the Bohemian Lands: Was Vivaldi's Music really used? Informazioni e studi vivaldiani, 14, 1993, pp. 51-73.

HANSELL, Sven - FREEMAN, E. Daniel. Bioni, Antonio. The New Grove dictionary of music and musicians. Volume 3, Baxter to Borosini / edited by Stanley Sadie; executive editor John Tyrrell. 2nd ed. New York: Grove, 2001, pp. 601-602.

HELFERT, Vladimír. Hudebni barok na českých zámcích. Jaroměrice za hraběte Jana Adama z Questenberku († 1752). Praha: Česká akademie císaře Františka Josefa pro vědy, slovesnost a umění, 1916.

JONÁŠOVÁ, Milada. I Denzio: tre generazioni di musicisti a Venezia e a Praga. Hudebni věda, 2008, vol. XLV, Nr. 1-2, pp. 57-114.

MATTHESON, Johann. Grundlage einer Ehrenpforte (Hamburg 1740), hrsg. von Max Schneider. Graz: Akademische Druckund Verlagsanstalt, 1994.

MATTHESON, Johann. Die drei Orchestre-Schriften. I, Das neu-eröffnete Orchestre. 3. Aufl. Laaber: Laaber, 2007.

MARKSTROM, Kurt Sven. The operas of Leonardo Vinci, Napoletano. Opera series, no. 2. Hillsdale - New York: Pendragon Press, 2007.

PEGAH, Rashid-Sascha. Antonio Bioni und seine „Cantate Musicali“ für Markgräfin Friderique Louise von Brandenburg-Ansbach. Jahrbuch für fränkische Landesforschung, 2012, vol. 72, pp. 185-198. 
PERUTKOVÁ, Jana. Der glorreiche Nahmen Adami. Johann Adam Graf von Questenberg (1678-1752) als Förderer der italienischen Oper in Mähren. Wien: Hollitzer Verlag, 2015.

PERUTKOVÁ, Jana. František Antonín Míca ve službách hraběte Questenberga a italská opera v Jaroměricich. Praha: KLP - Koniasch Latin Press, 2011.

PERUTKOVÁ, Jana. Problematika galantního stylu ve světle dobových pramenů (s bližším zaměřením na hudebně dramatickou tvorbu). Musicologica Brunensia, 2011, vol. 46, Nr. 1., pp. 127-139.

SARTORI, Claudio. I libretti italiani a stampa dalle origini al 1800: catalogo analitico con 16 indici. Cuneo: Bertola \& Locatelli, 1990-1994.

SCHODTERER, Hanna. Pietro Antonio Metastasios Azione teatrale, La pace fra la virtù e la bellezza in Vertonungen für den Wiener Hof von Luca Antonio Predieri und Antonio Bioni. Master thesis (supervisor: Reinhard Strohm), Universität Wien, Wien 2011.

SPÁC̆ILOVÁ, Jana. Antonio Vivaldi a italská opera v Brně: Orlando furioso a Tullo Ostilio (1735). Opus musicum, 2008, vol. 40, Nr. 4, pp. 22-27.

SPÁČILOVÁ, Jana. Hudba na dvoře olomouckého biskupa Schrattenbacha (1711-1738). Př́spěvek k libretistice barokni opery a oratoria. Dissertation thesis. Brno: Faculty of Arts MU, 2006.

SPÁČILOVÁ, Jana. Odraz hudebních kontaktů olomouckých biskupů 18. století v kroměřížské hudební sbírce. Musicologica Olomucensia, 2015, vol. 22, pp. 97-107.

SPÁČILOVÁ, Jana. Počátky opery ve Slezsku - současný stav pramenů. Musicologica Brunensia, 2016, vol. 51, Nr. 2, pp. 157-170.

SPÁČILOVÁ, Jana. Sarriho opera Didone v Brně (1734) a její rekonstrukce pro novodobé provedení (2014). Opus musicum, 2014, vol. 46, Nr. 1, pp. 18-31.

VEVERKOVÁ, Zuzana. Antonio Bioni a jeho kantáta Innocente v kroměřžské hudebni sbirce. Bachelor thesis (supervisor: Jana Spáčilová). Brno: Faculty of Arts MU, 2009.

VEVERKOVÁ, Zuzana. Antonio Bioni - životní osudy a tvorba neznámého skladatele. Opus musicum, 2012, vol. 44, Nr. 3, pp. 38-47.

WALTHER, Johann Gottfried. Bioni Antonio. Musikalisches Lexikon oder musikalische Bibliothek 1732 / J.G. Walther; herausgegeben von Richard Schaal. Kassel: Bärenreiter, 1953.

WEGGRZYN - KLISOWSKA, Walentyna. Barokowy teatr operowy we Wroctawiu 1725-1734. Wrocław: Polskie Stowarzyszenie Pedagogów Śpiewu, 2006. 